\title{
CARBON LOSS AFFECTED BY FIRES ON VARIOUS FORESTS AND LAND TYPES IN SOUTH SUMATRA
}

\author{
Hengki Siahaan ${ }^{1 *}$, Adi Kunarso ${ }^{1}$, Agus Sumadi ${ }^{1}$, Purwanto $^{1}$, Teddy Rusolono ${ }^{2}$, Tatang Tiryana ${ }^{2}$, \\ Hendy Sumantri ${ }^{3}$, and Berthold Haasler ${ }^{3}$ \\ ${ }^{1}$ Environment and Forestry Research and Development Institute of Palembang \\ Jl. Kol H. Burlian Km 6.5 Puntikayu Palembang, Indonesia \\ ${ }^{2}$ Faculty of Forestry, Bogor Agricultural University \\ Jl. Lingkar Akademik Kampus IPB, Dramaga, Bogor, West Java, Indonesia \\ ${ }^{3}$ Biodiversity and Climate Change Project (Bioclime) \\ Jl. Jenderal Gatot Subroto, Manggala Wanabhakti Building, Block VII, $6^{\text {th }}$ Floor, Jakarta 10270, Indonesia
}

Received: 8 November 2019, Revised: 20 March 2020, Accepted: 27 March 2020

CARBON LOSS AFFECTED BY FIRES ON VARIOUS FORESTS AND LAND TYPES IN SOUTH SUMATRA. Forest and land fires are the primary sources of emissions in South Sumatra. In line with the national policy, South Sumatra Province commits to reduce emissions, including emissions from forest and land fires. This research was aimed to assess carbon loss affected by fire in 2015 that covered three districts in South Sumatra, i.e. Musi Banyuasin, Banyuasin, and Musi Rawas. The study was conducted by re-measurement of carbon stocks plots on four forests and land types, i.e. secondary peat swamp forest, secondary dryland forest, bushes swamp, and forest plantation. Carbon stocks measuring was conducted on sample plots in a rectangular shape of $20 \mathrm{~m} \times 50 \mathrm{~m}$ of size for various types of natural forests and circle shape with a radius of $11.29 \mathrm{~m}(0.04 \mathrm{ha})$ and $7.98 \mathrm{~m}(0.02 \mathrm{ha})$ respectively for forest plantations of $<4$ years and $>4$ years old. Furthermore, carbon stocks in each plot were measured for three carbon pools of above-ground biomass, deadwood and litter. The result shows that carbon loss was varying with each forest and land type. The most significant number of carbon loss occurred on secondary peat swamp forest of $94.2 \mathrm{t} / \mathrm{ha}$ that is equivalent to the emission of $345.4 \mathrm{t} \mathrm{CO}_{2}$ eq. The second-largest carbon loss occurred on secondary dryland forest of $36.3 \mathrm{t} / \mathrm{ha}$ followed by forest plantation and bushes swamp of $18.5 \mathrm{t} / \mathrm{ha}$ and $13.5 \mathrm{t} / \mathrm{ha}$, respectively. The enormous carbon loss on secondary peat swamp forest and forest plantation occurred on above-ground biomass pool but in secondary dry forest and bushes swamp occurred on the deadwood pool.

Keywords: Carbon loss, forest fires, and forest types

KEHIL ANGAN CADANGAN KARBON AKIBAT KEBAKARAN PADA BERBAGAI TIPE HUTAN DAN LAHAN DI SUMATERA SELATAN. Kebakaran hutan dan lahan merupakan sumber emisi yang besar di Sumatera Selatan. Sejalan dengan kebijakan nasional, Provinsi Sumatera Selatan berkomitmen untuk mengurangi emisi, termasuk emisi dari kebakaran butan dan laban. Penelitian ini bertujuan untuk menilai kehilangan cadangan karbon akibat kebakaran hutan dan lahan pada berbagai srtatum/ tipe butan di Sumatera Selatan tabun 2015. Penelitian dilakukan dengan pengukuran ulang pada plot-plot pengukuran cadangan karbon yang terbakar tabun 2015 yang mencakup 3 kabupaten di Sumatera Selatan, yaitu Kabupaten Musi Banyuasin, Banyuasin, dan Musi Rawas. Kebilangan cadangan karbon dibitung dengan membandingkan cadangan karbon sebelum dan sesudah terbakar pada 4 stratum/tipe butan yang terbakar yaitu butan rawa gambut sekunder, butan lahan kering sekunder, semak belukar rawa, dan butan tanaman. Pengukuran stok karbon dilakukan pada plot berbentuk, persegi berukuran $20 \mathrm{~m} \times 50 \mathrm{~m}$ untuk berbagai tipe butan alam dan berbentuk. lingkaran dengan jari-jari 11,29 m dan 7,98 m masing-masing untuk. butan tanaman dengan umur $<4$ tabun dan $>4$ tahun. Selanjutnya, stok karbon pada masing-masing plot diukur untuk. 3 pool karbon, yaitu di atas permukaan tanah, kayu mati dan seresah. Hasil penelitian menunjukean bahwa kehilangan cadangan karbon bervariasi pada setiap stratum/ tipe butan. Kehilangan karbon terbesar terjadi pada hutan rawa gambut sekunder sebesar 94,2 t/ ha atau setara dengan emisi $345+\mathrm{CO}_{2}$ eq/ha. Kehilangan terbesar kedua terjadi pada butan laban kering sekunder sebesar 36,3 t/ ha dan berikutnya pada butan tanaman sebesar 18,5 t/ ha dan semak. belukar rawa sebesar 13,5 t/ ha. Pada butan rawa gambut sekunder dan

*Corresponding author: hengki_siahaan@yahoo.co.id 
butan tanaman kehilangan karbon terbesar terjadi pada pool karbon biomass atas permukaan sedangkan pada butan lahan kering sekunder dan semak belukar rawa, terjadi pada pool karbon kayu mati.

Kata kunci: Kehilangan karbon, kebakaran butan, dan tipe butan

\section{INTRODUCTION}

Forest and land fires affect the environment and human life seriously. In Sumatra Island, especially in South Sumatra, forest and land fires tend to occur repeatedly (Miettinen, Hooijer, \& Wang, 2012) and almost every year. The last fire occurred in South Sumatra at the end of 2015 is thought to had the most significant impact on the environment and the economy after the 1997-1998 fires (Adriani, Moyer, Kendrick, Henry, \& Wood, 2016). To solve the problem, the Indonesian government has made various efforts to prevent the occurrence of fire, either through their efforts through the program of Ministry of Environment and Forestry, or through international mechanism (Dharmawan, Arifanti, Lugina, Naito, \& Eko, 2013; Wibowo, 2010).

Loss of carbon stock and biodiversity are some of the effects of forest and land fires on the environment. Repeated fires kill the majority of trees, reduce canopy cover by half, and favouring invasive grass (Balch et al., 2015). The fire is also a considerable contributor to emissions, mainly if it occurs on peatland. South Sumatra Province is one of the peatland areas in Indonesia and over the years has been a significant contributor to the emissions from forest and land fires (Agus, 2013; Gustina, 2014; Krisnawati, 2010).

In line with policies at the national level, the provincial government of South Sumatra has committed to reducing emissions, mainly from the forestry and peatland sectors, either through self-employment or through international cooperation mechanism. REDD+ (Reducing emissions from deforestation and forest degradation, the role of conservation, sustainable forest management, and enhancement of forest carbon stocks) is one of the international mechanism to reducing emissions from forestry and peatland sector that is implemented at the sub-national level. REDD + implementation requires the Forest Reference Emission Level (FREL) as a basis of measuring the performance of reducing emissions; therefore, REDD+ implementation in a province requires a FREL arranged explicitly in a region with a high level of detail (tier 3) (Manuri, Lingenfelder, \& Steimann, 2011).

As a basis for the specific FREL compiling with a high level of detail, Provincial Forestry Service of South Sumatra and Ministry of Environment and Forestry, in collaboration with GIZ Bioclime have prepared the high level of detail of emission factors on various types of forests in South Sumatra. The research was done by establishing 112 sample plots which are spread over seven forest types (primary dryland forest, secondary dryland forest, primary mangrove forest, secondary mangrove forest, primary peatland forest, secondary peatland forest, and forest plantation) and three types of non-forest areas, i.e. estate cropping, shrubland, bushes swamp (Tiryana et al., 2016). In addition, as the area of peat distribution that often suffers to fires, the arrangement of FREL in South Sumatra must take into account the emissions sourced from fires and peat decomposition.

Forest and land fires in South Sumatra in 2015 occurred with high intensity and extensive area coverage. The fires also occurred on sample plots that were used to prepare the emissions factor on various forest types in South Sumatra. Therefore, this research was aimed to assess the carbon loss affected by fires with the remeasurement of the burnt sample plots. The 
Table 1. Locations and forest types of assessing the carbon losses in South Sumatra after fires in 2015

\begin{tabular}{|c|c|c|c|}
\hline No. & Forest type & Location & Sample Plots \\
\hline 1. & Secondary peat swamp forest & Merang Kepahyang peatland forest & $111,113,114,115,405,406$ \\
\hline 2. & Bushes swamp & $\begin{array}{l}\text { Merang Kepahyang peatland forest, } \\
\text { KPHP Lakitan, SM. Bentayan } \\
\text { Dangku }\end{array}$ & $527,528,173,378$ \\
\hline 3. & Secondary dryland forest & SM. Bentayan Dangku & 316,351 \\
\hline 4. & Forest plantation & $\begin{array}{l}\text { Eucalyptus plantation of PT. Musi } \\
\text { Hutan Persada (MHP) }\end{array}$ & $14,68,76$ \\
\hline
\end{tabular}

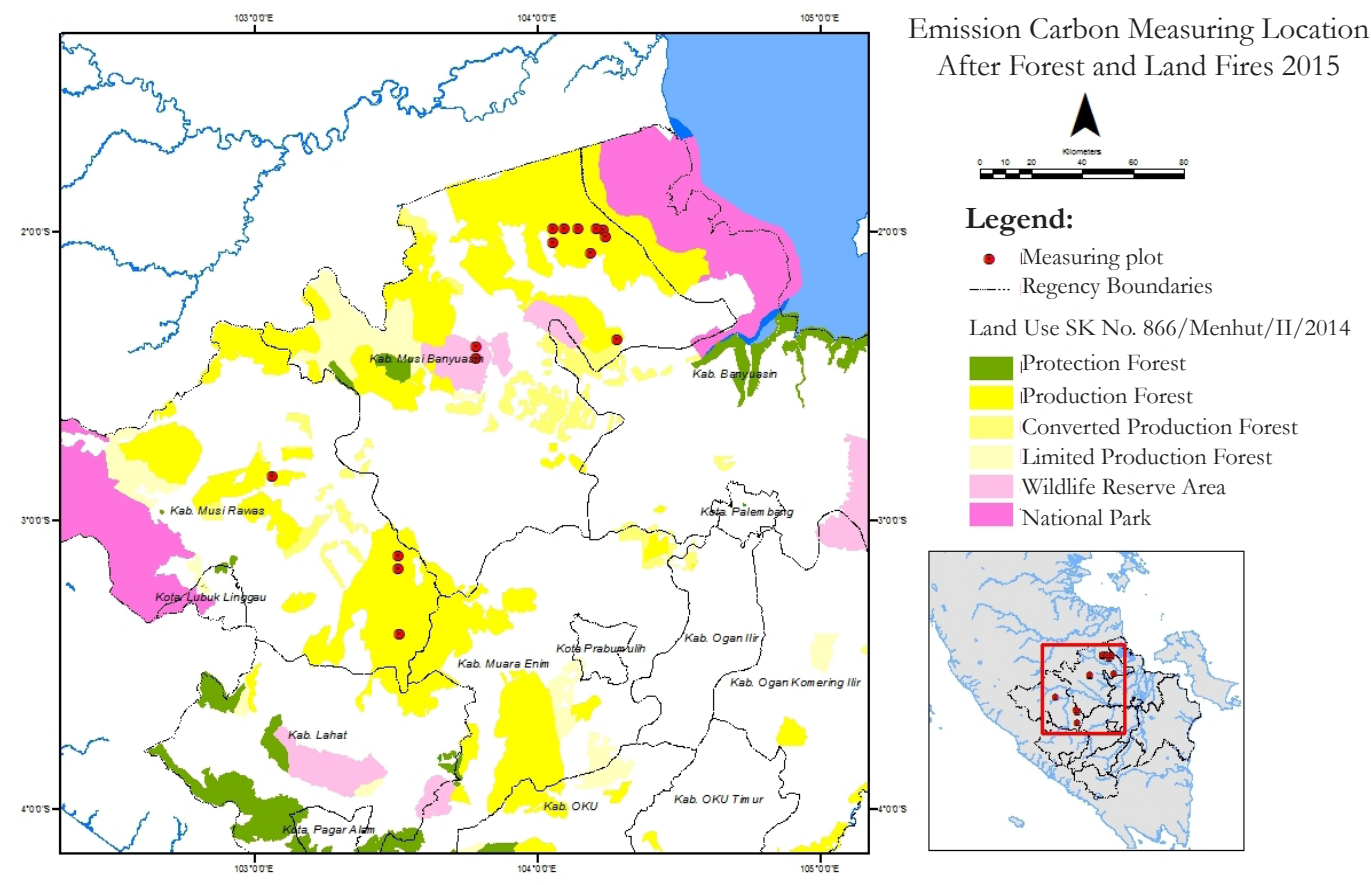

Figure 1. Site map of sample plots for assessing the carbon loss after fires on various forest and land types in South Sumatra

result of the study can be used as one of the information required for the preparation of the FREL document in South Sumatra.

\section{MATERIAL AND METHOD}

\section{A. Location}

Research location for assessing carbon loss affected by fires was done on the burnt areas at the end of 2015. The location includes three districts in South Sumatra, i.e. Musi Banyuasin, Banyuasin, and Musi Rawas districts and covers four forest and land types, i.e. secondary peat swamp forest, secondary dryland forest, bushes swamp, and forest plantation. Data collection was done by re-measurement of burnt sample plots established before the fires in 2015 (Tiryana et al., 2016). The plot placement was done by stratified systematic sampling design, but the number of sample plots on each forest type is determined by the size of the burnt area occurred in each plot. The sample plots in each location are presented in detail in Table 1, and the site map is shown in Figure 1.

\section{B. Establishment of Sample Plots}

The amount of carbon loss affected by forest and land fires can be calculated by comparing the carbon stock before and after the occurrence of the fires. The methods 


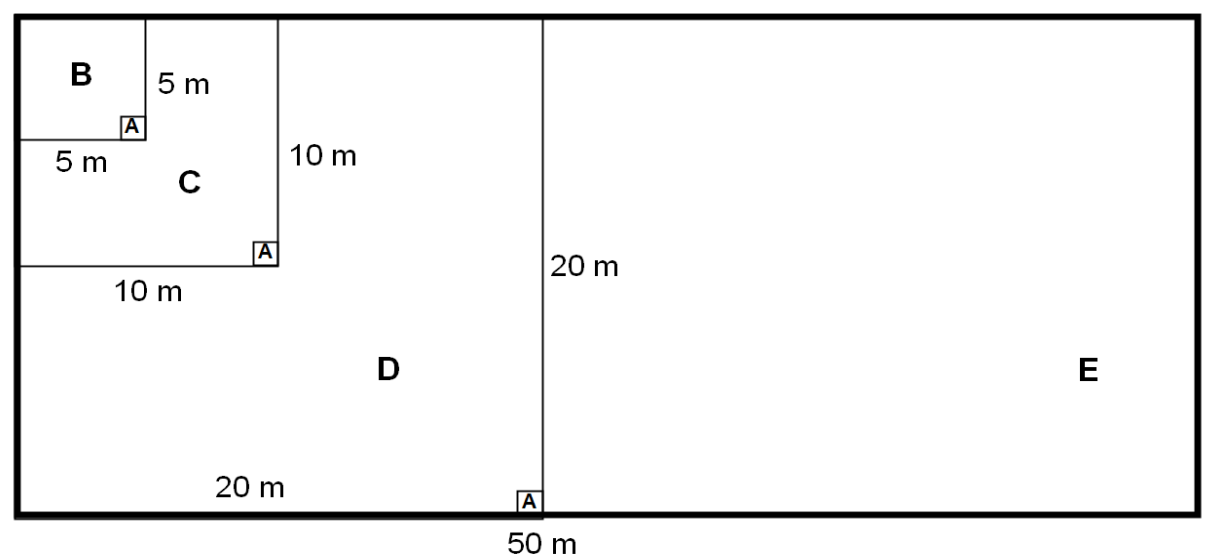

Figure 2. The size of the rectangular sample plots for carbon assessment in natural forest and mixed cultivated

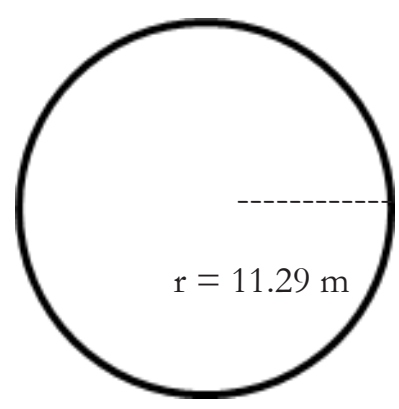

(a)

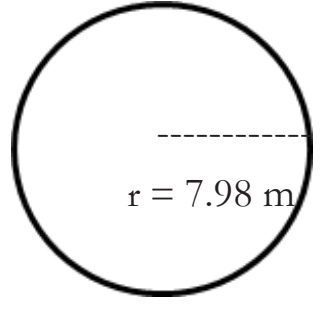

(b)

Figure 3. The size of the circle sample plots for carbon assessment in a forest and estate plantations:

(a) age $<4$ years and (b) age $>4$ years

used refers to the Survey of Carbon Stock and Biodiversity in South Sumatra Guidance (Rusolono, Tiryana, \& Purwanto, 2015).

The sample plot is a rectangular shape of $20 \mathrm{~m} \times 50 \mathrm{~m}$ used for various types of natural forest, shrubland, and cultivated area (Figure 2). In the forest plantation and estate crop which composed of uniform vegetation, the measurement is relatively simple; therefore the sample plot is a circle shape (Figure 3). The radius of the circle sample plot is adjusted to the age of the plant. In forest plantation with the age of plant $<4$ years, a circle plot with radius $7.98 \mathrm{~m}$ (area $=0.02 \mathrm{ha})$ is used and if the age of plant $>4$ years, the radius of the circle plot is $11.29 \mathrm{~m}$ (area $=0.04 \mathrm{ha}$ ).

\section{Data Analysis}

The measurement and the analysis of carbon stock on the various forest types after fires in this study are restricted to 3 carbon pools, i.e. above-ground biomass (AGB), deadwood (DW), and litter (LTR). Carbon stock analysis on each pool was performed following the IPPC Guidelines 2006 and the Guidance of Carbon Stock and Biodiversity Survey in South Sumatra (Rusolono et al., 2015).

\section{The measurement of above-ground biomass}

Carbon pool on the above-ground biomass is the carbon stored in the live plants which consist of woody plants and understory vegetation. Woody plants were divided into four stages of growth based on the diameter of breast height (dbh), i.e. sapling (dbh 5-9 $\mathrm{cm})$, pole (dbh 10-19 cm), medium tree (dbh 20-34 cm) and large tree (dbh $\geq 35 \mathrm{~cm})$. Carbon stock measurement of woody plants performed on subplots B (5 m x $5 \mathrm{~m}), \mathrm{C}$ (10 
Table 2. Allometric models used for assessing the above-ground biomass

\begin{tabular}{llll}
\hline \multicolumn{1}{c}{ Tree species } & \multicolumn{1}{c}{ Allometric model } & Location & \multicolumn{1}{c}{ References } \\
\hline $\begin{array}{l}\text { Forest plantation } \\
\text { Eucalyptus pellita }\end{array}$ & $\mathrm{W}_{\mathrm{ag}}=0.0678 * \mathrm{D}^{2.579}$ & South Sumatra & Onrizal et al. (2009) In: \\
& & & $\begin{array}{l}\text { Krisnawati, Imanuddin, \& } \\
\text { Adinugroho (2012) } \\
\text { (Manuri et al., 2014) }\end{array}$ \\
$\begin{array}{l}\text { Peatland forest } \\
\text { mixed species }\end{array}$ & $\mathrm{W}_{\mathrm{ag}}=0.15 \mathrm{D}^{2.095 *} \varrho^{0.664 *} \mathrm{H}^{0.552}$ & Riau, South Sumatra & Asia, Africa, America \\
$\begin{array}{l}\text { Dryland forest } \\
\text { mixed species }\end{array}$ & $\mathrm{Wag}=0.0673\left(\varrho^{*} \mathrm{D}^{2 *} \mathrm{H}\right)^{0.976}$ & (Chave et al., 2014) \\
\hline
\end{tabular}

$\mathrm{m} \times 10 \mathrm{~m}), \mathrm{D}(20 \mathrm{~m} \times 20 \mathrm{~m})$, and $\mathrm{E}(20 \mathrm{~m} \times 50$ $\mathrm{m})$, (Figure 2) respectively, for a sapling, pole, medium and large tree. Understory vegetation covers all live plant above ground with a height below 1.5 meters. Carbon stock measurement of understory vegetation was performed on subplot A of $0.5 \mathrm{~m} \times 0.5 \mathrm{~m}$ which was repeated three times on the corner of subplots B, C, and D.

Two methods measured carbon stock on above-ground biomass. Carbon stock on the understory vegetation was assessed by weighing the biomass directly to get the gross weight and then the sample was taken to get the dry weight in the laboratory. In this way, the dry weight or biomass of understorey vegetation per unit area in tons/ha was obtained. Meanwhile, the biomass of woody plants was assessed by measuring diameter and height of plants on each subplot and using allometric models appropriate for the forest types and the location where they were found (Table 2). Carbon stock on biomass was calculated by using the conversion factor of 0.47 (IPPC, 2006).

\section{The measurement of litter}

Litter is the remnants of dried and accumulated plant parts on the forest floor. The litter is restricted for the plant parts in the form of leaves, twigs, and the tree branches fallen on the forest floor with the diameter size of $<10$ $\mathrm{cm}$. The measurement of biomass on the litter was performed on the same subplot as for the understory vegetation, that is on subplot $\mathrm{A}$, a rectangular plot of $0.5 \mathrm{~m} \times 0.5 \mathrm{~m}$ was used. The understory vegetation and the litter were separated before each biomass was weighed to get their gross weight. Furthermore, from the samples of litter 300 gram was taken to get the dry weight in the laboratory.

\section{The measurement of deadwood}

Deadwood (necromass) is dead trees and their parts, which consisted of standing deadwood and fallen deadwood. Standing deadwood is classified into four classes of decay, i.e. class 1 , 2,3 , and 4 in accordance to the guidance of carbon stock and biodiversity survey in South Sumatra (Rusolono et al., 2015). Based on the guidance, each of the decay class is explained as follows:

- Class 1: the dead tree with much branch and twig but does not have leaves

- Class 2: the fallen tree with the branch but does not have a twig and leaves

- Class 3: the dead tree with no branch but the stem still complete

- Class 4: the fallen tree with a broken stem like a stump.

Furthermore, the biomass of standing deadwood was calculated using the allometric model of live trees (Table 2) and then multiplied with the correction factor of $0.9,0.8$ and 0.7 respectively for standing deadwood class 1,2 , and 3. Whereas for standing deadwood class 4 , the biomass was calculated by equation (1). The density of standing deadwood class 4 used in equation (1) is the result of the previously performed carbon stock survey (Table 3 ).

$$
\mathrm{W}_{\mathrm{dw} 4}=0.25 \pi(\mathrm{D} / 100)^{2} * \mathrm{~T} * \mathrm{f} * \mathrm{WD}
$$

Remarks: $\mathrm{Wdw} 4=$ dead wood biomass class 4, $\mathrm{D}=$ stem diameter $(\mathrm{cm}), \mathrm{T}=$ height $(\mathrm{m}), \mathrm{f}=$ form factor $(0.6)$, and $\mathrm{WD}=$ wood density of deadwood. 
Table 3. The average density of standing deadwood and fallen dead wood in various types of forest in South Sumatra

\begin{tabular}{lccc}
\hline \multicolumn{1}{c}{ Deadwood types } & Class & Average $\left(\mathrm{g} / \mathrm{cm}^{3}\right)$ & Standard Deviation $\left(\mathrm{g} / \mathrm{cm}^{3}\right)$ \\
\hline Standing dead wood & 1 & 0.559 & 0.092 \\
& 2 & 0.351 & 0.099 \\
& 3 & 0.389 & 0.107 \\
Fallen dead wood & 4 & 0.308 & 0.094 \\
& 1 & 0.560 & 0.175 \\
& 2 & 0.441 & 0.159 \\
& 3 & 0.354 & 0.153 \\
\hline
\end{tabular}

Source: References: Tiryana et al. (2016)

Tabel 4. Carbon stock of above-ground biomass $(A G B)$ before and after fires in various forest types in South Sumatra

\begin{tabular}{lcccccc}
\hline $\begin{array}{c}\text { Forest } \\
\text { type }\end{array}$ & \multicolumn{2}{c}{ Carbon stock of AGB before the fires ( $\mathrm{t} / \mathrm{ha})$} & \multicolumn{3}{c}{ Carbon stock of AGB after the fires $(\mathrm{t} / \mathrm{ha})$} \\
& WP & UV & Total & WP & UV & Total \\
\hline SPSF & $105.3 \pm 56.9$ & $0.1 \pm 0.1$ & $105.4 \pm 56.8$ & $3.4 \pm 5.3$ & $1.7 \pm 0.5$ & $5.1 \pm 5.0$ \\
BS & $20.0 \pm 16.3$ & $1.7 \pm 2.3$ & $21.8 \pm 15.7$ & $17.9 \pm 5.7$ & $3.5 \pm 1.9$ & $21.4 \pm 7.1$ \\
SDF & $75.5 \pm 22.2$ & $0.0 \pm 0.0$ & $75.5 \pm 22.2$ & $68.7 \pm 8.7$ & $0.5 \pm 0.3$ & $69.2 \pm 22.2$ \\
FP & $15.9 \pm 17.2$ & $3.5 \pm 1.9$ & $19.5 \pm 16.3$ & $0.0 \pm 0.1$ & $2.1 \pm 0.7$ & $2.1 \pm 16.3$ \\
\hline
\end{tabular}

Remarks: WP = woody plants, UV = understory vegetation, $\mathrm{SPSF}=$ secondary peat swamp forest, $\mathrm{BS}=$ bushes swamp, SDF = secondary dryland forest, $\mathrm{FP}=$ forest plantation

The measurement of the biomass of fallen dead wood was performed by the volumetric method. Based on this method, the biomass is obtained by multiplying the volume of fallen deadwood with its density. The density of fallen dead wood was adjusted to the result of carbon stock and biodiversity survey in South Sumatra (Tiryana et al., 2016) as shown in Table 3 . The fallen wood volume was calculated with equation (2).

$$
\mathrm{V}_{\mathrm{ldw}}=0.25 \pi\left(\left(\mathrm{D}_{\mathrm{p}}+\mathrm{D}_{\mathrm{u}}\right) / 200\right)^{2} . \mathrm{L}
$$

Remarks: Vldw $=$ volume of fallen dead wood, $\mathrm{Dp}=$ large end diameter, $\mathrm{Du}=$ small end diameter, and $\mathrm{L}=$ length of fallen dead wood

\section{RESULT AND DISCUSSION}

\section{A. Carbon Loss on Above Ground Biomass}

Carbon loss affected by the fire on aboveground biomass (AGB), mainly occurs in woody plants. The highest carbon loss occurs in secondary peat swamp forest, i.e. in Merang
Kepahyang forest area. The result shows that above-ground biomass of woody plants on peat swamp forest is high before the fire (Figure 4), an average of $105.3 \mathrm{t} / \mathrm{ha}$ and after the fire, only $3.4 \mathrm{t} / \mathrm{ha}$ is left, meaning there is a carbon loss of $101.9 \mathrm{t} / \mathrm{ha}$ or $96.77 \%$ of the initial amount (Table 4). The second-largest carbon loss of woody plants of above-ground biomass occurred in forest plantation, amounting to 15.9 $\mathrm{t} / \mathrm{ha}$. Still, from the percentage point of view, carbon loss in this forest type is the largest, reaching almost $100 \%$. Carbon loss of woody plants of above-ground biomass on secondary dryland forest and bushes swamp is relatively small, at $6.8 \mathrm{t} / \mathrm{ha}(9 \%)$ and $2.1 \mathrm{t} / \mathrm{ha}(10.5 \%)$ respectively.

Differences in the numbers of carbon losses in different forest types are caused by differences in land characteristics in each forest type. This occurs because the natures and intensity of fires are influenced by the characteristics of the land where the fire occurred. Based on soil types, in 

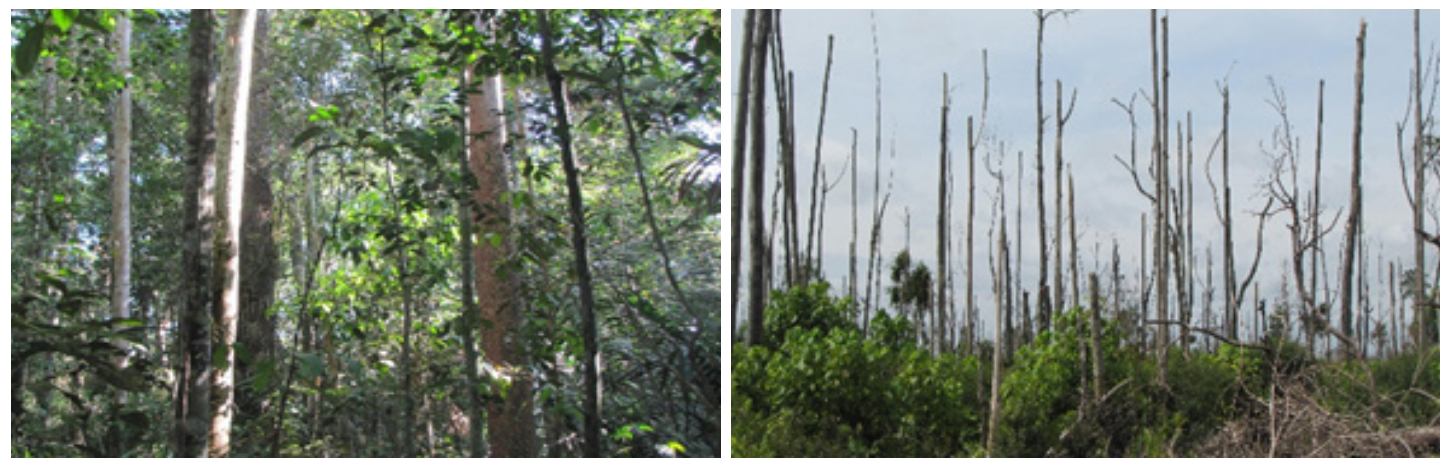

Figure 4. The condition of forest cover in Merang Kepahyang peat swamp forest before (left) and after fires (right)

the land and forest fires in South Sumatra in 2015 it was found that hotspots mostly occurred on peat soil, i.e. 180 hotspots with a hotspots density of 0.048 hotspots $/ \mathrm{km}^{2}$ (Tata, Narendra, \& Mawazin, 2017). Fires in peat swamp forest containing thick, soft material cause fires not only to occur on the surface but also can reach up to the tree roots. Dry peat with shallow moisture after the last extreme drought will become a very combustible fuel (Ardiansyah, Boer, \& Situmorang, 2017; Subiksa, Hartatik, \& Agus, 2011). Fires like this will last a long time and will cause the whole tree to die. This is in contrast to fires in other forest types, which generally occur only on the surface so that most existing trees are still alive after the fires.

Table 4 also shows that the fires do not affect the carbon stock of the understory vegetation of the above-ground biomass. Carbon stock on the understory vegetation tends to increase after the fires. This happens because \pm 1.5 years after the fires, understory vegetation has grown rapidly at that location, that could be larger in number than before the fires. Research on 2015 peatland fires in Jambi Province also shows that carbon stock of understory vegetation grows until it reaches 7.74 tons/ha after three years of fires (Hamzah, Napitupulu, \& Muryunika, 2019). However, because of the small percentage of understory species on aboveground biomass, the increase of carbon stock on the pool is not significant against the total above-ground biomass.

\section{B. Carbon Stock Loss on Litter}

The changes in carbon stock on litter differ for each forest type. In secondary peat swamp forest (SPSF) and Bushes Swamp (BS), there is a decrease of carbon stocks of the litter, and adversely there is an increase in secondary dryland forest (SDF) and forest plantation (FP) as shown in Table 5 . The accumulation of litter on the forest floor is coming from the deciduous leaves and twigs from the forest tree. The litter

Table 5. Carbon stock of the litter before and after fires on various forest types in South Sumatra

\begin{tabular}{ccc}
\hline Forest type & Carbon stock of litter before fires $(\mathrm{t} / \mathrm{ha})$ & Carbon stock of litter after fires $(\mathrm{t} / \mathrm{ha})$ \\
\hline SPSF & $4.1 \pm 1.1$ & $2.4 \pm 1.6$ \\
BS & $4.0 \pm 2.9$ & $2.2 \pm 1.6$ \\
SDF & $2.5 \pm 1.3$ & $3.8 \pm 1.0$ \\
FP & $1.5 \pm 0.2$ & $3.4 \pm 1.9$ \\
\hline
\end{tabular}

Remarks: SPSF= secondary peat swamp forest, BS = bushes swamp, SDF = secondary dryland forest, FP $=$ forest plantation 
that existed before the fire were thought to have been burned so that the litter that existed after the fires was a litter that accumulated after the fires until the measurement.

In the secondary peat swamp forest (SPSF) and bushes swamp (BS), carbon stock of the litter before the fires is quite large, reaching 4.0-4.1 tons/ha. All of the litter burns in the fire, after which the accumulation of the litter occur again, but the amount does not reach the original amount. The opposite happens in forest plantation (FP) and secondary dryland forest $(\mathrm{SDF})$, in both forest types there is an increase of carbon stock of the litter. This increase is thought to occur due to the decay of branches and twigs after burning. Most of the trees in both forest types are not dead, but tree parts, in the form of branch and twigs, have dried and decayed some time after burning. After the tree growth returns to normal, physiologically, the leaves and branches that are aging, will be the source of litter accumulation. Furthermore, many research indicates that carbon stock on litter does not have a significant contribution to total carbon stock in many forest types (Dibaba, Soromessa, \& Workineh, 2019; Takahashi et al., 2010; Ullah \& Al-Amin, 2012).

\section{Carbon Loss of Deadwood}

Carbon stock of deadwood (DW) generally decreased after fires, except in secondary peat swamp forest (Table 6). The most considerable carbon loss of deadwood occurs in secondary dryland forest, amounting to $31.4 \mathrm{t} / \mathrm{ha}$ or $(76.2 \%)$ from that of before fires (41.2 $\mathrm{t} / \mathrm{ha})$.
Most of the carbon loss occurs due to the burning of standing deadwood trees that before burning was $38.9 \mathrm{t} / \mathrm{ha}$ and declined to $5.8 \mathrm{t} /$ ha after the fires. The second-largest carbon loss of deadwood occurs on bushes swamp, amounting to $11.2 \mathrm{t} / \mathrm{ha}$ or $61.20 \%$ from that of before fires.

In contrast to 3 other forest types, carbon stock of deadwood (DW) in secondary peat swamp forest has increased. This happens because, after the fires, the living trees at that location die and become standing deadwood (SDW) and fallen deadwood (FDW). Carbon stock of standing deadwood in secondary peat swamp forest increased by $3.2 \mathrm{t} / \mathrm{h}$ a or $47.06 \%$ from that of before fires, while fallen dead wood increased by $4.6 \mathrm{t} / \mathrm{ha}$ or $52.87 \%$. Increase of carbon stock on deadwood after forest disturbance also happens in the humid tropical forest in Sabah, Malaysia, where live tree carbon storage decreased exponentially with increasing forest degradation 7-10 times after logging. In contrast, deadwood increased until it reached $50 \%$ of above-ground carbon stocks (Pfeifer et al., 2015).

\section{Total Carbon Loss}

Total carbon stock is the sum of carbon stock of above-ground biomass (AGB), carbon stock of litter, and carbon stock of deadwood (DW). The three-carbon pools are directly affected by the fires, thus becoming an important indicator in assessing the impact of fires on carbon dioxide $\left(\mathrm{CO}_{2}\right)$ emissions. The largest total carbon loss occurs in secondary peat swamp

Table 6. Carbon stock of deadwood before and after fires in various forest types in South Sumatra

\begin{tabular}{|c|c|c|c|c|c|c|}
\hline \multirow{2}{*}{$\begin{array}{l}\text { Forest } \\
\text { type }\end{array}$} & \multicolumn{3}{|c|}{$\begin{array}{l}\text { Carbon stock of dead wood } \\
\text { before fires }(t / h a)\end{array}$} & \multicolumn{3}{|c|}{$\begin{array}{c}\text { Carbon stock of dead wood } \\
\text { after fires }(\mathrm{t} / \mathrm{ha})\end{array}$} \\
\hline & SDW & FDW & Total & SDW & FDW & Total \\
\hline SPSF & $3.6 \pm 4.3$ & $8.7 \pm 6.4$ & $12.3 \pm 5.8$ & $6.8 \pm 9.0$ & $13.3 \pm 6.0$ & $20.1 \pm 10.3$ \\
\hline BS & $17.0 \pm 18.9$ & $1.3 \pm 1.3$ & $18.3 \pm 19.0$ & $6.2 \pm 7.4$ & $0.8 \pm 0.6$ & $7.1 \pm 7.6$ \\
\hline SDF & $38.9 \pm 13.1$ & $2.3 \pm 0.7$ & $41.2 \pm 13.8$ & $5.8 \pm 8.1$ & $4.1 \pm 2.5$ & $9.8 \pm 10.6$ \\
\hline FP & $6.5 \pm 9.6$ & $0.1 \pm 0.1$ & $6.6 \pm 8.5$ & $0.8 \pm 1.3$ & $2.8 \pm 3.0$ & $3.6 \pm 4.2$ \\
\hline
\end{tabular}

Remarks: $\mathrm{SDW}=$ standing dead wood, $\mathrm{FDW}=$ fallen dead wood, $\mathrm{SPSF}=$ secondary peat swamp forest, $\mathrm{BS}=$ bushes swamp, $\mathrm{SDF}=$ secondary dryland forest, $\mathrm{FP}=$ forest plantation 
Table 7. Total carbon loss affect by fires on various forest types in South Sumatra

\begin{tabular}{lccc}
\hline Forest type & $\begin{array}{c}\text { Total carbon stock } \\
\text { before fires }(\mathrm{t} / \mathrm{ha})\end{array}$ & $\begin{array}{c}\text { Total carbon stock after } \\
\text { fires }(\mathrm{t} / \mathrm{ha})\end{array}$ & $\begin{array}{c}\text { Total carbon stock loss } \\
(\mathrm{t} / \mathrm{ha})\end{array}$ \\
\hline SPSF & $121.8 \pm 57.7$ & $27.6 \pm 15.6$ & $94.2 \pm 51.4$ \\
BS & $44.1 \pm 21.4$ & $30.6 \pm 12.7$ & $13.5 \pm 23.2$ \\
SDF & $119.2 \pm 9.7$ & $82.9 \pm 8.7$ & $36.3 \pm 0.9$ \\
FP & $27.6 \pm 17.0$ & $9.1 \pm 5.7$ & $18.5 \pm 11.3$ \\
\hline
\end{tabular}

Remarks: SPSF= secondary peat swamp forest, BS= bushes swamp, SDF $=$ secondary dryland forest, FP= forest plantation

Table 8. Carbon stock loss on each carbon pool affected by fires in various forest types in South Sumatra

\begin{tabular}{|c|c|c|c|c|c|c|c|c|}
\hline \multirow{2}{*}{ Forest type } & \multicolumn{3}{|c|}{ AGB (t/ha) } & \multirow{2}{*}{ LTR } & \multicolumn{3}{|c|}{ Deadwood } & \multirow{2}{*}{$\begin{array}{l}\text { Total } \\
\text { carbon }\end{array}$} \\
\hline & WP & UV & Total & & SDW & FDW & Total & \\
\hline SPSF & 101.8 & -1.6 & 100.3 & 1.7 & -3.2 & -4.6 & -7.8 & 94.2 \\
\hline BS & 2.1 & -1.8 & 0.4 & 1.9 & 10.7 & 0.5 & 11.3 & 13.5 \\
\hline SDF & 6.8 & -0.5 & 6.3 & -1.4 & 33.2 & -1.8 & 31.3 & 36.3 \\
\hline FP & 15.9 & 1.4 & 17.3 & -1.9 & 5.8 & -2.8 & 3.0 & 18.5 \\
\hline
\end{tabular}

Remarks: $\mathrm{AGB}=$ above ground biomass, $\mathrm{WP}=$ woody plants, $\mathrm{UV}=$ understory vegetation, $\mathrm{LTR}=$ litter, $\mathrm{SDW}=$ standing dead wood, $\mathrm{FDW}=$ fallen dead wood, $\mathrm{SPSF}=$ secondary peat swamp forest, $\mathrm{BS}=$ bushes swamp, $\mathrm{SDF}=$ secondary dryland forest, $\mathrm{FP}=$ forest plantation

forest, amounting of $94.2 \mathrm{t} / \mathrm{ha}$ (Table 7) which is equivalent to the emission of $345.4 \mathrm{t} \mathrm{CO}_{2} \mathrm{eq} /$ ha. This result is confirmed by any research of the fire of 2015 in Indonesia, especially in South Sumatra. The estimated burned area in South Sumatra during El Nino was 422,718 ha, of which most of them (61.64\%) occurred in peatland particularly in Musi Banyuasin District (Ardiansyah et al., 2017; Tata et al., 2017). Globally fires of 2015 in Indonesia contributed with the emission of 0.8 to $1.9 \mathrm{Gt} \mathrm{CO}_{2}$ eq (Ministry of Environment and Forestry, 2015) Similar result of carbon loss also occurred in Lenga Beech Forest, Patagonia, Argentina, with severely burned areas losing carbon stock of 90.7-104.6 ton/ha (Bertolin, Urretavizcaya, \& Defosse, 2015).

Most of the carbon loss on secondary peat swamp forest is the result of the loss of above-ground biomass which burns out or turns into dead wood, so the carbon stock of deadwood increased after fires as shown in Table 8. Fire in peatland is one of the most critical environmental problems in South East Asia including Indonesia which undergone recurrent fires particularly in South Sumatra (Konecny et al., 2016; Kumar, Adelodun, Khan, Krisnawati, \& Garcia-Menendez, 2020).

The second-largest emissions are the result of fires in secondary dryland forest, resulting in carbon loss of $36.3 \mathrm{t} / \mathrm{ha}$, which is equivalent to emissions of $133.1 \mathrm{t} \mathrm{CO}_{2} \mathrm{eq} / \mathrm{ha}$. In contrast to the secondary peat swamp forest, most of the carbon losses in the secondary dryland forest are the result of the burning of deadwood. Carbon loss in bushes swamp and forest plantation respectively are $18.5 \mathrm{t} / \mathrm{ha}$ and 13.5 $\mathrm{t} /$ ha or equivalent to the emission of 67.8 t $\mathrm{CO}_{2} \mathrm{eq} / \mathrm{ha}$ and $49.47 \mathrm{t} \mathrm{CO}_{2} \mathrm{eq} / \mathrm{ha}$. In forest plantation, most of the emissions occur as the result of the loss of above-ground biomass. In this forest type, although the emissions are relatively small compared to other forest types, the fires result in substantial economic losses, since the above-ground biomass on this forest type is cultivated plant. 


\section{CONCLUSION}

Based on the analysis of the fire effect on the carbon stock losses in South Sumatra in 2015 , it can be concluded that carbon loss varies across forest types. The most considerable carbon loss occurs on secondary peat swamp forest amounting to $94.2 \mathrm{t} / \mathrm{ha}$ or equivalent to emissions of 345 t $\mathrm{CO}_{2} \mathrm{eq} / \mathrm{ha}$. The secondlargest carbon loss occurs in secondary dryland forest amounting to $36.3 \mathrm{t} / \mathrm{ha}$ and then on forest plantation and bushes swamp, respectively amounting to $18.5 \mathrm{t} / \mathrm{ha}$ and $13.5 \mathrm{t} /$ ha. In secondary peat swamp forest and forest plantation, the most significant carbon loss occurs on above-ground biomass pool. Still, in secondary dryland forest and bushes swamp, it happens on dead wood carbon pool.

\section{ACKNOWLEDGEMENT}

This study was financially supported by The GIZ Biodiversity and Climate Change (Bioclime) Project in collaboration with Environment and Forestry Research and Development Institute of Palembang. Authors grateful to Mr. Berthold Haasler (Bioclime) and Mr. Choirul Akhmad (Head of Environment and Forestry Research and Development Institute of Palembang) for the financial and moral support provided in carrying out this study.

\section{REFERENCES}

Adriani, M., Moyer, S., Kendrick, A., Henry, G., \& Wood, S. (2016). The cost of fire: An economic analysis of Indonesia's 2015 fire crisis. Jakarta.

Agus, F. (2013). Konservasi dan rehabilitasi lahan gambut untuk penurunan emisi karbon: Aplikasi untuk Provinsi Sumatera Selatan. In D. Purwito, T. E. Komar, A. Subiakto, Kuntadi, Haryono, \& S. Suri (Eds.), Prosiding Workshop ITTO Project RED-SPD 009/09 Rev.2 (F), Stakeholder Consultation The Application of Method and Technologies to Enhance the Restoration of PSF Ecosystem (pp. 1-18). Pusat Penelitian dan Pengembangan Konservasi dan Rehabilitasi (P3KR), Bogor.
Ardiansyah, M., Boer, R., \& Situmorang, A. (2017). Typology of land and forest fire in South Sumatera, Indonesia based on assessment of MODIS Data. Earth and Environmental Science, 54(012058), 1-7. doi://10.1088/17551315/54/1/012058.

Balch, J. K., Brando, P. M., Nepstad, D. C., Coe, M. T., Silvério, D., Massad, T. J., ... Carvalho, K. S. (2015). The susceptibility of southeastern Amazon Forests to fire: Insights from a large-scale burn experiment. BIoScience, 65(9), 893-905. doi://10.1093/biosci/biv106.

Bertolin, M. L., Urretavizcaya, M. F., \& Defosse, G. E. (2015). Fire emission and carbon uptake in severely burned lenga beech (Nothofagus pumilio) forest of Patagonia Argentina. Fire Ecology, 11(1), 32-55. doi://10.4996/ fireecology.1101032.

Chave, J., Rejou-Mechain, M., Burquez, A., Chidumayo, E., Colgan, M. S., Delitti, W. B. C., ... Vielledent, G. (2014). Improved allometric models to estimate the aboveground biomass of tropical trees. Global Change Biology, 20, 3177-3190. doi://10.1111/gcb.12629.

Dharmawan, I. W. S., Arifanti, V. B., Lugina, M., Naito, R., \& Eko, M. (2013). Enhanced approaches to estimate net emission reductions from deforestation and degradation of undrained peat swamp forests in Central Kalimantan, Indonesia. Pusat Penelitian dan Pengembangan Perubahan Iklim dan Kebijakan, Bogor.

Dibaba, A., Soromessa, T., \& Workineh, B. (2019). Carbon stock of the various carbon pools in Gerba - Dima moist Afromontane forest, South - western Ethiopia. Carbon Balance and Management, 14:1, 1-10. doi://10.1186/ s13021-019-0116-x.

Gustina, T. M. (2014). Strategi dan kebijakan Provinsi Sumatera Selatan untuk mencapai target penurunan emisi: Pengalaman dari penyusunan Rencana Aksi Daerah (RAD). In K. L. Ginoga, A. Pribadi, Z. Muttaqin, V. B. Arifanti, \& M. Lugina (Eds.), Strategi monitoring dan pelaporan plot sampel permanen di Provinsi Sumatera Selatan (pp. 11-32). Pusat Penelitian dan Pengembangan Perubahan Iklim dan Kebijakan, Bogor.

Hamzah, Napitupulu, R. R. P., \& Muryunika, R. (2019). Kontribusi cadangan karbon tanah dan tumbuhan bawah pada ekosistem gambut 
bekas tebakar sebagai karbon tersimpan di lahan tropika. Jurnal Silva Tropika, 3(1), 108117.

Konecny, K., Ballhorn, U. W. E., Navratil, P., Jubanski, J., Page, S. E., Tansey, K., ... Florian Siegert. (2016). Variable carbon losses from recurrent fires in drained tropical peatlands. Global Change Biology, 22, 1469-1480. doi://10.1111/gcb.13186.

Krisnawati, H. (2010). Status data stok karbon dalam biomas hutan di Indonesia. In N. Masripatin \& C. Wulandari (Eds.), REDD + \& Forest Governance (pp. 23-43). Pusat Penelitian dan Pengembangan Perubahan Iklim dan Kebijakan, Bogor.

Krisnawati, H., Imanuddin, R., \& Adinugroho, W. C. (2012). Allometric models for estimating tree biomass at various ecosystem types in Indonesia. Research and Development Center for Conservation and Rehabilitation, Bogor. doi://10.13140/RG.2.1.3090.6405.

Kumar, P., Adelodun, A. A., Khan, M. F., Krisnawati, H., \& Garcia-Menendez, F. (2020). Towards an improved understanding of greenhouse gas emission and fluxes in tropical peatlands of Southeast Asia. Sustainable Cities and Society, 101881. doi://10.1016/j.scs.2019.101881.

Manuri, S., Brack, C., Puji, N., Hergoualc, K., Novita, N., Dotzauer, H., ... Widyasari, E. (2014). Forest ecology and management tree biomass equations for tropical peat swamp forest ecosystems in Indonesia. Forest Ecology and Management, 334, 241-253. doi://10.1016/j.foreco.2014.08.031.

Manuri, S., Lingenfelder, \& K.H., Steimann. (2011). Tier 3 biomass assessment for baseline emission in merang peat swamp forest. In Workshop on Tropical Wetland Ecosystem of Indonesia (pp. 1-9). CIFOR, Bogor.

Miettinen, J., Hooijer, A., \& Wang, J. (2012). Peatland degradation and conversion sequences and interrelations in Sumatra. Reg Environ Change, 12, 729-737. doi: doi.org/10.1007/s10113012-0290-9.

Ministry of Environment and Forestry. (2015). Understanding estimation of emission from land and forest fires in Indonesia 2015. Jakarta.
Pfeifer, M., Lefebvre, V., Turner, E., Cusack, J., Khoo, M., Chey, V. K., ... Robert M Ewers. (2015). Deadwood biomass: An underestimated carbon stock in degraded tropical forests? Environmental Research Letters, 10(4),1-11. doi://10.1088/1748-9326/10/4/044019.

Rusolono, T., Tiryana, T., \& Purwanto, J. (2015). Panduan survei cadangan karbon dan keanekaragaman flora di Sumatera Selatan. Deutsche Gesellschaft fur Internationale Zusammenarbeit (GIZ), Palembang.

Subiksa, I., Hartatik, W., \& Agus, F. (2011). Pengelolaan lahan gambut secara berkelanjutan. In N. L. Nurida, A. Mulyani, \& F. Agus (Eds.), Pengelolaan Lahan Gambut Berkelanjutan (pp. 73-88). Bogor.

Takahashi, M., Ishizuka, S., Ugawa, S., Sakai, Y., Sakai, H., Ono, K., ... Morisada, K. (2010). Carbon stock in litter, deadwood and soil in Japan's Forest Sector and its comparison with carbon stock in agricultural soils. Soil Science \& Plant Nutrition, 56, 19-30. doi://10.1111/ j.1747-0765.2009.00425.x.

Tata, H. L., Narendra, B. H., \& Mawazin. (2017). Tingkat kerawanan kebakaran gambut di Kabupaten Musi Banyuasin, Sumatera Selatan. Jurnal Hutan Tanaman, 14(1), 51-71.

Tiryana, T., Rusolono, T., Siahaan, H., Kunarso, A., Sumantri, H., \& Haasler, B. (2016). Cadangan karbon butan dan keanekaragaman flora di Sumatera Selatan. German International Cooperation (GIZ), Palembang.

Ullah, M., \& Al-Amin, M. (2012). Above- and below-ground carbon stock estimation in a natural forest of Bangladesh. Journal of Forest Science, 58(8), 372-379.

Wibowo, A. (2010). Measureable, Reportable dan Verifyable (MRV) untuk Emisi Gas Rumah Kaca dari kegiatan Kehutanan. In $\mathrm{N}$. Masripatin \& C. Wulandari (Eds.), REDD+ $\&$ Forest Governance (pp. 3-21). Pusat Penelitian dan Pengembangan Perubahan Iklim dan Kebijakan, Bogor. 